\title{
Research on the Management Innovation of Family Business in the South of Fujian Province
}

\author{
Linjing Chen \\ TSL School of Business and Information Technology \\ Quanzhou Normal University \\ Quanzhou, China 362000
}

\begin{abstract}
In recent years, the development of market economy in southern Fujian province, represented by Quanzhou, has made remarkable achievements and taken a road of market economy development with local characteristics. Among them, family enterprises have developed rapidly. However, there are also many drawbacks. Based on the analysis of the status quo and the restrictive factors of the current family business in southern Fujian province, this paper discusses the main path and strategy of management innovation of family-owned enterprises.
\end{abstract}

Keywords-the south region of Fujian province; family business; management; innovation

\section{INTRODUCTION}

Since the reform and opening-up, the development of market economy in southern Fujian province, represented by Quanzhou, has made remarkable achievements and taken a road of market economy development with unique local characteristics. And it has become one of the most rapid and dynamic development areas of market economy in Fujian province and the whole country. Private economy occupies more than $80 \%$ of the national economy in the south of Fujian province. And private economy has become the characteristics, pillar and source of the economy in the south of Fujian province. However, $90 \%$ of the private economy is family business. The drawbacks of family management have become the hindrance to the sustainable development. And the management innovation of the family business is imperative.

\section{DEFINITION OF FAMILY BUSINESS}

The definition of family business in domestic and foreign economic circles is consistent with the opinion of the American scholar Chandler. That is to say, the family business is an economic organization which owns all or part of the ownership and management rights [1]. Domestic scholars have defined the family business from different angles. And they have made the conclusion that family business is an economic organization which is composed of all or most of the property rights, including the critical control right and the main management right under the company system. And it is owned by a family and carries out the family management.
Family business is not a naturally backward type of enterprise. And it is universal enterprise. In fact, whether developing countries or developed countries, family businesses are living and developing in a large number. And they have a pivotal position in the national (regional) economy. For example, $40 \%$ of the top 500 companies in the world are family businesses. Many famous large companies such as DuPont, Ford, Kodak, Amway, Motorola and so on are family companies.

\section{The Status QUO OF THE DEVElopMENT OF FAMILY BUSINESS IN THE SOUTH OF FUJIAN PROVINCE}

Taking Quanzhou as an example, as of the end of 2017 there are more than 50,000 private enterprises in Quanzhou (excluding individual industrial and commercial households). More than $90 \%$ of the private enterprises in Quanzhou adopt the family management model. After several years of development, many family-owned enterprises in Quanzhou have stepped into the stage of large-scale development from the initial start-up stage. However, most of them still maintain the family-based business relations.

During the "11th Five-Year Plan", the number of private enterprises and individual industrial and commercial households in Quanzhou increased rapidly. Especially, under the background of financial crisis, the number of private enterprises and individual industrial and commercial households in Quanzhou increased. And the impact of financial crisis was minimal. The most centralized private capital of textile shoes and clothing, building materials, technology products, food and beverage, equipment manufacturing, paper printing and other new business has become new highlight of economic development. These fully reflect the huge vitality of the private economy. That is to say, the family-based private enterprises will have rapid development in the future.

\section{CONSTRAINTS ON THE DEVELOPMENT OF FAMILY BUSINESS IN THE SOUTH OF FUJIAN PROVINCE}

\section{A. The Internal Property Rights of Family Business Are not Clear, and the Structure of Property Rights Is Highly Closed}

The limits of original property rights of some enterprises are still vague. And the final ownership has not been 
decomposed into natural persons. The actual share of the largest shareholder of family business is more than 50\%, and some even reach $90 \%$. The enterprise has experienced the growth period. Especially, when the enterprises face the situation of joint-stock system or financing, all kinds of property rights problems have emerged.

The property right is closed, and the tradability is poor. Most of the family businesses still insist that the stock right is not liberalized.

It is held by family members, relatives and friends who start the business together. It is very difficult for senior professional managers and potential foreign investors to get involved in the property right of the enterprise.

\section{B. To Improve Internal Governance Mechanism of Family Business}

The quality of entrepreneur is innate, and there is paternalistic decision-making. Most of the family entrepreneurs in the south of Fujian province have low level of education and practical experience. However, due to lack systematic modern management knowledge and the culture of transition to modern entrepreneurs, it has a great impact on the sustainable development of family business. In the management mechanism, the entrepreneurs often have the management with feelings and experiences instead of scientific management. The trust, affection and human feeling would replace the restraint of the system. They put emphasis on centralized management and neglect the decentralized management. This paternalistic decisionmaking lacks effective monitoring, feedback and restriction from both inside and outside. It would easily lead to blindness in business decision-making. And the development of enterprises would deviate from the correct direction.

The enterprise lacks effective incentive mechanism. It is difficult to attract foreign outstanding high-level talented person. In recent years, many family enterprises have fully realized the importance of bringing in talents, especially high-level talents. However, there are many problems in the introduction of high-level talents. First, the number of talents is small. The proportion is very low. Second, the enterprises can't retain these introduced high-level talents. First of all, the enterprises have not given a high degree of trust and full rights to the introduced talents. Secondly, for the introduced high-level talents, the enterprise would adopt the pay system of annual salary or salary plus. However, it lacks effective long-term incentives of technology stock, management stock, stock options and so on.

The enterprise management system is not perfect, and the management method is rather rough. There are main factors affecting the institutionalization construction and institutionalization management. First, it is the system. The main performance is that the system has not become an integrated system. Each system does not have clear rules of effectiveness. It only has the entity system. However, there is no procedure system to guarantee the implementation of the system. Second, when the system is in conflict with the interests of the family, the family opinion can transcend the system. Many enterprise leaders have not completed the transition from human management to rule management. Third, the enterprise leaders believe that the institutionalization construction and management is the constraints and restrictions of their own rights. And it often has weak implementation. At the same time, much family business management is still relatively rough. Especially, professional management is not standardized. The management level needs to be improved.

\section{Family Business Lacks Long-term Strategic Planning, and Its Development Strategy would Be Affected by Emotional Factors Easily}

There are some problems of family business in strategic management. (1) It lacks clear and long-term strategic objectives. Family enterprises are short-sighted or vague in strategic objectives. They lack long-term planning and rational strategic thinking. (2) It lacks scientific strategic decision-making process. In the process of strategic decisionmaking, it has not been able to make a comprehensive analysis of the opportunities, threats and advantages and disadvantages of the external environment. And they can't use scientific decision-making means. They wouldn't make correct decisions relying on the collective wisdom and experience. (3) The choice of strategic plan is arbitrary. When the enterprises formulate the strategic plan, they would "follow the feelings". Their appraisal and choice of the plan has little consideration of competitive advantage and the resource restriction of the enterprises. Even, they would regard "the diversification" as one kind of fashion. Finally, due to blind follow-up, it may lead to the enterprise's decline and loss.

\section{The Technological Innovation Ability of Family Enterprise Is Insufficient, and It Lacks the Competitiveness}

At present, many family enterprises obviously lack the innovation ability. It is the "soft rib" to restrict the enterprise to become bigger and stronger. For a long time, most small and medium-sized enterprises still passively imitate or rely on external forces to solve the technical needs. They focus on the expansion. However, they don't value the improvement of the quality and the science and technology. And this phenomenon is still more common. There are some main factors that restrict the innovation ability of enterprises. (1) The willingness and motivation of independent innovation of entrepreneurs is insufficient. Especially, the family business in Quanzhou is mostly small and mediumsized enterprise. The fund is insufficient for a long time. And the technology is weak. And the imitation method often becomes their most realistic choice under the present condition. (2) The technical force of enterprises is weak. Another major obstacle to technological innovation is the shortage of technology developers. (3) The effective external technical network has not been formed. Most of the family enterprises have not formed the development, transformation, introduction, and absorption and service system. The technological progress and innovation has no support system. The enterprises have little relationship with tertiary institutions and scientific research institutions. They have no 
information and guidance. The exchanges among family businesses are very little. And they can't share the resources.

\section{E. The Family Business Lacks Excellent and Perfect Enterprise Culture Support}

The enterprise culture is the soul of enterprise and the high level of management means of modern enterprise. In recent years, family enterprises have paid more and more attention to the construction of corporate culture. And some enterprises have distinctive features. For example, Joeone, Anta and other brand enterprises have distinctive features. However, for most private family businesses, to build good corporate culture is still the weakness for them. It is mainly embodied in the following aspects. (1) The construction of enterprise culture is one-sided and formalistic. Some enterprises simply equate corporate culture with image design. Some enterprises believe that corporate culture is to establish and implement the rules and regulations of the enterprise. Some enterprises believe that group culture and the entertainment is corporate culture. (2) It one-sidedly pursues maximum benefits and lacks higher value. The family enterprise has the stronger utilitarianism in the value idea. At first, this kind of utilitarianism value is helpful to the initial growth of the enterprise. With the development and expansion of enterprises, operating with the purpose of profitability will inevitably lead to one-sided and strategic blindness in decision-making. (3) With the plagiarism of enterprise culture, it lacks the individuality in the construction of enterprise culture. Some enterprises blindly imitate and copy the culture of other domestic enterprises regardless of their own actual situation. Few enterprises can cultivate their own characteristics of corporate culture through accumulation, selection and digestion.

\section{F. The Inheritance of Family Business Is a Prominent Problem that Puzzles the Family Business}

Most of the first generation of entrepreneurs in the family business is more than fifty years old. To break the fate that the family business could be rich for only three generations, and to realize the smooth inheritance of the family business and keep the sustainable development of the family business has become the first problem that the family business owners in Quanzhou must face. At present, some family enterprises have carried on generation-to-generation alternation. And the second generation of managers has successfully taken over the enterprises. For example, PEAK, ANTA, Xtep, ERKE and other brand enterprises have successfully realized generation-to-generation alternation. The premise of success is inseparable from the entrepreneur's forward-looking planning. On the contrary, quite a number of family businesses have great obstacles in the transfer of power. The entrepreneurs are caught in the trap of rights. They are attached to power and unwilling to delegate power. In this case, they would ignore the selection or training of successors. There are too many candidates for the heirs. It would cause power struggle within the family. The entrepreneur does not have the ability or the desire to inherit the father's business.

\section{STRATEGIES FOR THE MANAGEMENT INNOVATION OF FAMILY BUSINESS IN THE SOUTH OF FUJIAN PROVINCE}

\section{A. To Clarify the Internal Property Rights and Establish the Property Rights System Adapting to the Development Stage of Enterprises}

Property right system is a fundamental system of enterprises. It directly determines the formation of corporate governance structure and its management framework. And it is the primary condition for enterprises to enhance competitiveness and improve business performance. According to the different factors such as the human resources inside and outside the family and the development stage of the enterprise, the family enterprise should choose the appropriate ownership structure.

It adopts closed type of equity. That is to say, the family members hold $100 \%$ of the shares. However, it can be improved in weakening the management right of family enterprise, introducing professional managers and modern management system. For example, the world's top furniture manufacturers are Sweden's IKEA and China's Lee Kum Kee Group. IKEA and Lee Kum Kee choose closed equity structure. However, the enterprise can grow and operate successfully. It needs some unique conditions. First, in the intergenerational inheritance, the stock has been maintained in the hands of family members. Second, the family has strong human resources to support this structure. Third, it would adopt more open and transparent management model. Closed ownership does not mean that the right to operate is also closed. The enterprise can take the socialized operation. If the family business does not meet the above-mentioned requirements, they should consider other types of equity structure. Especially, when the scale of the enterprise becomes larger, they should also gradually open the equity.

The family has the control, and the degree of dispersion of equity is low. The family controls at least $51 \%-90 \%$ of the equity of the enterprise. However, the equity should be gradually open to the senior management, the employees and institutional investors of the enterprise. Family holding can effectively stimulate the great enthusiasm of family management, and prevent the struggle for controling the company. However, at the same time, the equity should be opened appropriately in due course. It is an effective medium and long-term incentive way to open the stock right to the senior managers of enterprises other than family members. It plays an unparalleled role in introducing and retaining excellent professional managers and cultivating the loyalty and dedication of professional managers. It is possible to consider expanding the scope of equity for ordinary employees. And it would close the relationship between employees and enterprises, encourage the enthusiasm of employees, and provide strong driving force for the sustainable development of enterprises. It would also alleviate the mobility of staff of many enterprises in Quanzhou and the difficulty of recruiting workers. And it is helpful to the stability of the workforce.

Equity should be open to the top of the enterprise and employees. Also, it can be open to institutional investors. 
Especially, when the enterprise is in certain scale, in order to further expand the enterprise, it can consider to gradually opening the equity to institutional investors.

It is the relative holding of the family and the high degree of socialization of the stock right. Under the premise of controlling the equity of the enterprise, the family enterprise should absorb the equity of the external legal person, including the strategic investor and the social investor. And then, it could follow the development of the family enterprise. The listed family enterprises generally take the holding method. The equity is highly dispersed. The degree of socialization is higher. If the enterprises take this type of equity, they need to pay attention to a few points. First, the enterprise should have core competitiveness. Especially, they must have their own brand. And the brand must be very strong. Second, before the socialization of stock right, the management right should be socialized first. And the enterprise should carry out standardized, scientific and modern management. Third, the proportion of family holding should be appropriate. In the case of China, holding shares cannot generally be less than $35 \%$. And then, it would reduce the possibility to be secretly acquired.

No matter what type of ownership structure reform is adopted, the property right structure within the family enterprise must be clear. If the family members cannot reach a consensus on the clear property right through internal discussion, the enterprise can use the "external force" to solve the problem. For instance, the enterprises could carry on second start-up and collectivization transformation, implement new merger strategy, and absorb new shareholders. With the replacement of new and old opportunities, they could redefine the original equity. And then, it would achieve the clear property right.

\section{B. To Desalinate the Management Right of Family and Realize the Transformation from Family Management to Professional Management}

The enterprise should make the reform of the traditional family management. Many scholars advocate the complete separation of ownership and management rights in accordance with the standards of the modern enterprise system. This way of thinking is not realistic for the majority of family enterprises in the south of Fujian province. The family enterprises in the south of Fujian province should take the governance road which can not only embody the right of family management, but also can gradually dilute the control of the management right. At the same time, it would give full play to the professional advantages of professional managers.

And the efforts could be made to build this governance model in several ways:

It should dilute the right to operate the family enterprise and break the monopoly of the family in the governance structure. It is suggested that the family enterprise should control the two important decision-making positions of chairman and general manager. The family enterprises should strictly control management positions such as becoming employees of the enterprise. And the position of general manager can be considered to be filled by excellent professional managers. The enterprises should establish a complete set of personnel mechanism to introduce excellent talent, overcome the cronyism, and change the family management to the manager management.

It should establish scientific decision-making mechanism within the enterprise. When making important decisions, enterprise leaders should brainstorm, listen to the opinions of professionals, strengthen the scientific and democratic decision-making mechanism with the board of directors as the core rather than the boss as the individual core, and strengthen the regularization and institutionalization of decision-making procedures. And then, it would effectively reduce the random of decision-making and the risk of major decision-making mistakes. The enterprises could encourage the staff to participate in management and put forward reasonable proposals. Also, it could mobilize the enthusiasm, initiative and creativity of staff.

It should establish mutual trust mechanism between family enterprises and professional managers. The family enterprise should authorize the manager reasonably and effectively. In the delegation of authority, the scope of delegation should be clearly defined. And then, the grantee is aware of the objectives, responsibilities and rights of his or her works. After the delegation of authority, it must assume the responsibility of supervision. For their difficulties, it should give due help and encouragement. In addition, family business should give managers full trust. The enterprises can't make the interference beyond their authority after determining the principal-agent relationship.

It should establish reasonable and effective incentive and restraint mechanism and perfect internal governance mechanism. Enterprises must design a set of sound and effective incentive mechanism according to the actual situation. And they could take a variety of incentive measures to motivate the behavior of managers. The incentive mechanism of material benefit may consider the post salary, the annual salary system, the profit commission, the year-end welfare, the option stock right and so on. In addition to meeting the needs of managers for material interests, we should also pay attention to their needs for the social interests of career achievement, right status, social prestige, development opportunities and self-worth. Of course, in addition to the benefit incentive, we must establish the strict restraint mechanism. In the restraint aspect, the enterprise may adopt the company constitution restraint, the contract restraint, the procedure restraint and other internal restraint, legal restraint, the morals restraint, the market restraint, the social organization restraint and other social restraint mechanism.

\section{To Learn from Advanced Management Methods and Strive to Improve the Level of Institutionalized and Modern Management of Enterprises}

Management is the eternal theme of enterprises. And the level of management affects the survival and development of enterprises. Most of the family enterprises in the south of Fujian province have extensive traditional management methods. Faced with rising operating costs, shrinking profit 
margins and increasing market competition, the family enterprises must try to improve the institutionalized and modern management level of the enterprises, and strive to obtain profits from the management.

It should strengthen the institutionalization of enterprises. First of all, the family enterprise should perfect the enterprise system. And the system construction should cover the allround and whole process of the enterprise management. The systems should not overlap conflict and contradict each other. While establishing the entity system, the enterprise should establish the corresponding procedure. It is necessary to have special personnel in charge of the system management of the enterprise. The leaders and management of enterprises should take the lead in implementing the policy. They should strictly act in accordance with the system. In the end, it would achieve the transformation from human management to rule management.

It should draw lessons from the modern management to promote the management level. To introduce, absorb and digest the $5 \mathrm{~S}$ lean management system, the enterprise resources can be used effectively. And the waste can be reduced. The cost can be controlled by the management. And the enterprise could obtain the profit from the management. It should strengthen the information construction of enterprises, establish comprehensive CRM system, and improve customer satisfaction and loyalty. In accordance with the principle of "easy before difficult" and "divide before join", ERP management system covering enterprise finance, marketing, production logistics, service, office, research and development is gradually established to improve the efficiency of enterprise operation. It should pay attention to the network marketing, e-commerce and other new trade and marketing methods of research and application. Finally, it would achieve integration with traditional marketing.

\section{To Pay Attention to Strategic Management and Formulate Feasible Development Goals}

The development strategy is the soul and direction of an enterprise. The family enterprises in southern Fujian should strengthen the study of development strategy of the enterprises.

It should carry out strategic planning and formulate clear and feasible development strategy. The family enterprises should analyze the market, the user, the competition, the own resources and the ability and so on with the enterprise boss and the professional manager team. And they also should forecast the industry development prospect and the development direction scientifically; clarify the development direction and the development goal of the enterprises.

The strategy of specialization and steady development should be the first choice for family enterprises. In a certain stage of the development, many enterprises always want to try to seek diversification and high-speed expansion. The majority of family enterprises in the south of Fujian province are small and medium-sized enterprises. Both the capital strength and the management level are relatively weak. And the specialization and steady development is the ideal road for them.

\section{E. To Encourage Scientific and Technological Innovation and Enhance the Competitiveness of Family Enterprises}

Family-owned companies can enhance their technological capabilities by clarifying the orientation of multi-tiered family-owned companies' technological innovations and increasing technological development and introduction and technological input. And then, it would form their core competitiveness and competitive advantages.

It should define the technical innovation orientation of the family enterprise according to its own situation. For example, after 30 years of market-oriented reform and development, the family enterprises in Quanzhou have basically formed "pyramid" structure. "Spire" refers to limited liability Company, joint stock limited company and Group Company whose output value is more than 100 million yuan. "The middle of tower" refers to the enterprises whose output value is more than 10 million yuan. And they usually have certain scale and strength. "Tower bottom" refers to the enterprises whose value is more than ten to thousands of millions. According to its own circumstances, the family enterprise could make technical innovation in line with local conditions. The "spires" of the family business mature. The technological innovation of such enterprises should be based on endogenous independent innovation. The technological innovation can be used to seek for cooperation with enterprises. And these enterprises have relevant ability. Also, they could establish the industrialization channel of research and development achievements, including the trade channel of technology and the combination of research and development enterprises and enterprises with capital, market and manufacturing advantages. For example, the rapid development of "Anta" brand in recent years mainly benefits from continuous technological innovation and brand marketing innovation. "The middle of tower" enterprises are still in the growth stage. And they should strengthen the entrustment research and development; participate in the base cooperation, peripheral research and development organization. At the same time, they should strive to establish the internal co-construction research and development organization, speed up the introduction of scientific and technological talents, enhance their own technological innovation ability, and shorten the transformation from the introduction-oriented to independent innovation-oriented. Most of the "Bottom" enterprises are in the start-up period. And the way of technological innovation is mainly based on the introduction of exogenous technology digestion, absorption and tracking imitation. In keeping with this, technological innovation should be targeted at improving the ability to monitor and import technology or to obtaining scientific and technological resources. It should make full use of the public science and technology platform of the government, establish regular contact with scientific research institutions and technical service institutions, rely on scientific research institutions and technical service institutions to carry out technological innovation activities, establish the supply and demand technology chain with the 
cooperation units, and rely on the cooperation units to promote the product technology level of family enterprises. ${ }^{1}$

It should increase the intensity of technology development and technology investment. At present, the technological innovation ability of many family enterprises in the south of Fujian province is not strong. It is necessary to increase the intensity of technology development and investment, and perfect the investment guarantee system of technological innovation. Family enterprises in the south of Fujian province have a serious tendency to attach importance to imitation rather than research and development. Usually, they have low investment in research and development. And the ability of independent innovation is not strong. Therefore, family enterprises must attach great importance to the investment and management of technological innovation. On the other hand, the government should also increase the support to the technology innovation. It should create good policy environment and service environment for the enterprise innovation as far as possible. In addition to increasing municipal financial investment in science and technology, the government should focus on providing a sound and efficient public service platform that can share the benefits for the enterprise's technological innovation activities. And the government should formulate the guiding policy of science and technology and the industry. And it should formulate relevant policies and measures to attract and reward innovative talents. And it also should support and encourage the enterprise to provide the technological innovation ability.

It should strengthen the training and introduction of technical talents, and create an environment and atmosphere to attract and retain talents. The cultivation and introduction of innovative talents is the guarantee for technological innovation of family enterprises. And human capital is the most active factor in enterprises. In order to cultivate highquality scientific research talents, the enterprises should first increase the technical training for staff, cultivate their own talents, and further improve their own technology development ability. However, there are few universities and scientific research institutions in the south of Fujian province. And the training ability of enterprises is insufficient. It is necessary to rely on the strength of the government to introduce high-level innovative talents and strengthen the construction of innovative talents team.

\section{F. To Cultivate Unique Corporate Culture to Support the Sustainable Development of Family Enterprises}

The construction of enterprise culture should not be formalistic, and we must attach importance to the construction of cultural connotation. Generally speaking, corporate culture consists of three layers. The surface layer is the expression of corporate culture. The middle layer is the institutional layer. The core layer is the spiritual layer. That

Xu Jiqin. "Research on technological innovation of enterprises", Forum on Science and Technology in China, 2002.05 is to say, it is the essence of corporate culture. ${ }^{2}$ In order to do a good job in the construction of enterprise culture, it must go from the surface layer to the middle layer and then to the core layer step by step. It would instill the culture of the top and middle layers of the enterprise to all employees in the course of the establishment and development of the enterprise. Through education and integration, a set of unique value system and management ideas have been formed. We could know the advantage of the core culture. As an invisible cultural constraint force, the enterprise culture can make up for the deficiency of the rules and regulations, enhance the cohesion and external competitiveness of the enterprise, and internalize the enterprise staff into their own actual actions. And they could conscientiously abide by them.

It should carry forward the spirit of merchants of Fujian province, improve the quality of family enterprises and mold the culture of entrepreneur. Enterprise culture can be said to be entrepreneur culture in a specific sense. The leader of enterprise is the designer, advocates and builder of enterprise culture. And it plays an important role in the construction of enterprise culture. Therefore, in order to carry on the innovation of enterprise culture, the enterprise manager must change the idea, enhance comprehensive quality and the cultural level. We should have a clear understanding of the internal and external environment of the enterprise, choose the correct value standard and cultural connotation, and personally participate in the design of the enterprise culture.

The unique regional culture of the south of Fujian province makes the entrepreneurs have advanced spirit of Fujian merchants, such as "bearing hardships and standing hard work, dare to challenge, fighting hard and loving to fight". It is valuable spiritual wealth. Also, it can provide important help to the development of enterprises under the trend of economic globalization. In the process of the innovation of enterprise culture, carrying forward and inheriting the spirit of Fujian businessmen can show the excellent personal charm of entrepreneurs, enhance the confidence of employees and the brand image of enterprises, and establish strong belief to develop enterprises.

It should take the people-oriented management as the starting point, and realize the transformation from "small family culture" to "everybody culture". "Small family culture" is focused on family interests as the center. The idea of "everybody culture" is to emphasize the harmonious culture of social responsibility. It is composed of five elements, such as employees, customers, partners, society and shareholders. "Everybody" refers to put the staff and customers at the first position. The shareholders are put in the last. And then, it would form a family with a sense of social responsibility. ${ }^{3}$ "Everybody culture" is a kind of opening, promotion and revolution to the traditional family system of "small family culture". And it is in line with the

Wang Qingqi. "Corporate culture - The soft underbelly of sustainable development of family businesses", Journal of Taishan University, 2010.04

Mao Lixiang. Evergreen of family enterprise, Zhejiang People's Publishing House, 2008 
culture of modern market economy. Also, it is the most competitive culture for Chinese enterprises.

Based on the innovation, it should establish the enterprise culture with individuality characteristic of the enterprise. The enterprise culture is changeable. Each enterprise's development process is different. All of its response to the environment strategy and the way to deal with internal conflicts will have their own characteristics. To construct excellent enterprise culture, we should combine the general character with the individuality, the general character with the individual character organically. Under the guidance of the theory of enterprise culture, we should construct excellent enterprise culture which is full of characteristics and distinct individuality from the reality of the enterprise. And it can promote the development and progress of the enterprise. Belonging to Japanese culture, Sony's corporate culture emphasizes innovation. Nissan's corporate culture emphasizes customer first; Also, HP's corporate culture emphasizes adaptability to the market environment. IBM's corporate culture emphasizes respect and trust for people.

\section{G. To Plan Intergenerational Alternations as Early as Possible and Pay Attention to the Cultivation of Successors}

The inheritance of family business is an important strategic issue that relates to the future life and death of family business. There are two main modes in the selection of family business successors. One is the inheritance of family affection - the son inherits the father's work. Second, it is the inheritance of non-kinship - the talents can take over the enterprises. Family enterprises in the south of Fujian province should not stick to one model in the selection of successors. However, it should make preparations for both sides at the same time.

It should make plan for intergenerational alternations and attach importance to the training of successors. The fatherto-son business model is the preferred succession model of the family business. Choosing and training qualified enterprise successors is a complex system process. And the successful handover will take about 5-8 years, or even longer. It took GE of the United States 10 years to select Welch. However, most of the family enterprises in the south of Fujian province lack a complete succession plan or leadership training plan. Therefore, family business owners should put the issue of successor selection and training on the agenda as early as possible. In addition, the cultivation of potential heirs should pay attention to academic education and practical experience. Before entering the succession process, there should have enough time for the successor of family enterprise to start from the grass-roots level. And then, they can accumulate experience. They would go to the top management step by step. Finally, they could obtain the qualification of succession.

Through the safe and effective system arrangement, it creates the space for the member outside the family to inherit the enterprise. Entrepreneur should make it clear that the inheritance of enterprise depends on individual entrepreneur and the support of a relatively sound system. And entrepreneur is the director or screenwriter. Heng'an Group President $\mathrm{Xu}$ Lianjie believes that the system of family business should be standardized and transparent in the governance. If the talents are suitable for enterprise management, or they have the ability to drive the better development of the company, the enterprises would regard the talents as the successor.

It should inherit tangible assets such as enterprise wealth and intangible assets such as enterprise culture and enterprise spirit. Many owners of family business one-sidedly understand the inheritance of the family as the inheritance of blood and wealth. In fact, the highest realm of the inheritance of family business lies in the inheritance of culture. For example, 14 generations of DuPont has become a huge family business empire. And it has the history of more than 200 years. Its equity in the DuPont family is low. And its chief executives are not necessarily members of their family. However, they are family businesses. The family still holds certain stock equity in these enterprises. And many of the family members work in the enterprise. More importantly, these enterprises inherit the enterprise culture, enterprise value system and enterprise spirit that their predecessors started the enterprise. The spirit of the enterprise and the spirit of its family is one. And the strength of this spirit enables the enterprise to survive for a long time.

\section{CONCLUSION}

To sum up, there are indeed many problems in the management of family businesses in southern Fujian. It is necessary to explore ways to graft modern enterprise systems and traditional family systems to create a management model suitable for Chinese family businesses, which will not only give full play to the advantages of family management, but also absorbs and draws on the essence of modern enterprise system, so that a modern family management model with Chinese characteristics can be established.

\section{REFERENCES}

[1] Guo Fansheng. "China model: An outline for the growth of family businesses”. Peking University Press, 2009. 郭凡生.《中国模式: 家 族企业成长纲要》. 北京大学出版社 2009 年版

[2] Guo Yuejin. "Management of family enterprises". Economic Management Press, 2003. 郭跃进. 《家族企业经营管理》，经济管 理出版社 2003 年版

[3] He Junxiang. "Exploration of developmental ideas of intergenerational inheritance of family businesses". Journal of Zhejiang Normal University, 2009.2. 何军香. “国内家族企业代际 传承发展思路探究”，《浙江师范大学学报》，2009.2

[4] Lv Zhanfeng. "Summarization of several issues in the research of family enterprises in China". Theory Monthly, 2008.1. 吕占峰. “我 国家族企业研究的若干问题综述”，《理论月刊》，2008.1

[5] Cui Dongxia, Shen Yuzhi. "Analysis of management mode of family enterprises". Journal of Liaoning Technical University, 2006.11. 崔东 霞, 沈玉志. “民营企业家族式管理模式探析”，《辽宁工程技术 大学学报》, 2006.11

[6] Pan Shaobin, Meng Shaodong. "Challenges of family enterprises in Quanzhou - Construction of corporate culture", Market Weekly, 2005.1. 潘少斌、孟少东. “泉州家族制企业的成长挑战一一企业 文化建设”，《市场周刊》，2005.1 